\title{
Inspekcija cevovoda u eksploataciji i analiza uzroka otkaza
}

$\mathrm{O}$ prema pod pritiskom obuhvata posude, cevovode, sigurnosne uređaje, pomoćne uređaje pod pritiskom i pripadajuce delove ove opreme kao što su: prirubnice, spojnice, priključci, oslonci, uške za nošenje i drugi delovi slične namene [1].

Oprema pod pritiskom se prema opasnosti po zdravlje i bezbednost ljudi i okoline deli na opremu visokog nivoa opasnosti i opremu niskog nivoa opasnosti [1,2]. Oprema visokog nivoa opasnosti predstavlja pretnju za bezbednost ljudi i okoline, jer usled grešaka može da dodje do otkaza sa potencijalno katastrofalnim posledicama. Zbog toga "Pravilnik o pregledima opreme pod pritiskom tokom veka upotrebe" [2], između ostalog, propisuje zahteve za pregled i periodiku pregleda za svaki tip opreme pod pritiskom. Određivanje nivoa opasnosti i kategorije cevovoda se vrši prema dijagramima 6-9 Priloga I - Podela opreme pod pritiskom prema nivou opasnosti, "Pravilnika o pregledima opreme pod pritiskom tokom veka upotrebe ("Sl. glasnik RS”, br. 87/2011). Kod određivanja kategorije cevovoda merodavna veličina je nazivni prečnik, odnosno proizvod pritiska i nazivnog prečnika cevovoda. Osim ove dve veličine, za određivanje kategorije cevovoda, a time i nivoa opasnosti, potrebno je uzeti u obzir stanje fluida (tečno ili gasno) i grupu fluida (grupa 1 ili 2). Do otkaza cevovoda dolazi usled prekoračenja pritiska, korozije, neotkrivene greške u materijalu ili zavarenom spoju ili nestručnog rukovanja, ali i pojave hidrauličkog udara. Periodika ispitivanja je definisana Prilogom III - Rokovi redovnih periodičnih pregleda, "Pravilnika o pregledima opreme pod pritiskom tokom veka upotrebe ("Sl. glasnik RS", br. 87/2011). Spoljašnji pregled posuda pod pritiskom je predviđen na 5 godine, unutrašnji pregled nije predviđen a ispitivanje pritiskom na 5 godina. Gasovodi se ispituju prema "Pravilniku o uslovima za nesmetan i bezbedan transport prirodnog gasa gasovodima pritiska većeg od 16 bar" (“Sl. Glasnik RS”, br. 37/2013 I 87/2015).

\section{$1 \quad$ Uvod}

Pojedini cevovodi su u upotrebi preko 40 godina. Za njihov uspešan rad i bezbednost ljudi i okoline, inspekcija cevovoda predstavlja veoma važan segment u njihovom održavanju. Prema Upravi za bezbednost cevovoda i opasnih materija (PHMSA) [3] američkog odeljenja za saobraćaj, samo u SAD, u periodu između 1995. i 2014. godine, dogodilo se 360 smrtnih slučajeva, 1368 povreda i 894 incidenata $u$ vezi sa otkazom gasovoda nafte, gasa i opasnih fluida. $\mathrm{U}$ ovom radu je opisan značaj inspekcije cevovoda, koraci koje je potrebno preduzeti sa posebnim osvrtom na analizu rizika. Takođe, analizirani su uzroci i posledice otkaza cevovoda pod pritiskom.

\section{Ispitivanja novih cevovoda}

Tehnički zahtevi za projektovanje, izradu i ocenjivanje usaglašenosti cevovoda kod kojih je najveći dozvoljeni pritisak PS veći od 0,5 bar propisani su Pravilnikom o o tehničkim zahtevima za projektovanje, izradu i ocenjivanje usaglašenosti opreme pod pritiskom (“Sl. glasnik RS”, br. 87/2011).

Svi delovi cevovoda tokom izrade moraju biti podvrgnuti ispitivanju bez razaranja i sa razaranjem. Ova ispitivanja su propisana Pravilnikom i standardom SRPS EN 13480-5 [4].

Ispitivanja bez razaranja uključuju merenje debljine zida, provere mera (ovalnost, ugao savijanja itd.), ispitivanja tvrdoće, pregled ultrazvukom nepravilnosti po zapremini (unutrašnjih) u uzdužnom i poprečnom pravcu, pregled postojanja nepravilnosti na površini ili blizu površine (provera magnetnim česticama ili penetrantom), kopije površinske strukture u zoni naprezanja (u slučaju kada je potrebno praćenje tokom rada za primene cevi u području tečenja) [4].

Ispitivanja sa razaranjem uključuju ispitivanje zatezanjem, ispitivanje zatezanjem na povišenim temperaturama (kada se delovi koriste u području tečenja) ispitivanje udarom na epruveti sa zarezom, metalografska ispitivanja (npr. čelici sa $9 \%$ ili $12 \% \mathrm{Cr}$ ) i druga ispitivanja specificirana u EN 13480-2 ili u evropskom standardu za osnovni materijal.

Novi cevovodi moraju da budu podvrgnuti završnom ocenjivanju koje, sem vizuelnog pregleda, obuhvata i ispitivanje zadržavanja natpritiska u formi hidrostatickog pritiska.

\section{Inspekcija cevovoda tokom veka upotrebe}

Mnogi od cevovoda su preko 40 godina u upotrebi. Korozija i erozija smanjuju čvrstoću ovih struktura na vrednosti manje od projektovane, i promene u kapacitetu ili radu dovode do ozbiljnijih zahteva inspekcije i ispitivanja, nego što je prvobitno predviđeno. Otkazi cevovoda su rizik za gubitak života ljudi i štete po životnu sredinu. Glavni cilj za sprovođenje programa inspekcije cevovoda je da obezbedi da svaki hidrant sigurno i efikasno radi, kao i njegovo redovno održavanje. Neke od prednosti koje proizilaze iz redovnih inspekcija cevovoda su [5]:

- poboljšanje objekta i bezbednosti ljudi i okoline, 
- $\quad$ sprečavanje oštećenja životne sredine,

- poboljšanje pouzdanosti,

- $\quad$ smanjenje troškova rada i održavanja,

- minimiziranje neplaniranih ispada,

- minimiziranje odgovornosti.

\subsection{Učestalost inspekcije}

Učestalost inspekcije može da varira od 1 do 5 godina, ali ne sme da prelazi 5 godina.

Faktori koje treba uzeti u obzir da bi se preporučio datum sledeće inspekcije uključuju [5]:

- Pristupačnost za ispitivanje,

- Generalno stanje cevovoda,

- Tip projekta i starost cevovoda,

- Postojanje značajnih pitanja javne bezbednosti,

- Postojanje značajnih pitanja životne sredine,

- Potreba da se dokumentuje stanje cevovoda,

- Kritičnost objekta za proizvodnju energije.

Kada se ovi i drugi relevantni faktori uzmu u obzir, može da se odredi učestalost inspekcije, a minimalne smernice za njeno određivanje su sledeće:

- Letimični vizuelni pregled celog cevovoda treba da se vrši jednom mesečno od strane zaposlenog osoblja. Ako ovo nije praktično zbog prekomerne dužine cevovoda, nepristupačnog terena $\mathrm{i}$ drugih razloga, onda ispitivanje treba obaviti najmanje jednom godišnje.

- Spoljašnje površine cevovoda pod pritiskom je veoma poželjno vizuelno ispitati svake 2 do 3 godine da se utvrdi stanje obloga i premaza, a najduže na 5 godina.

- Temeljno ispitivanje cevovoda trebalo bi da se vrši svakih 5 godina.

\subsection{Procedura i plan inspekcije}

Procedure za inspekciju cevovoda u eksploataciji treba da uključe sledeće [6]:

1. Izvršiti inicijalnu procenu, koja uključuje temeljno vizuelno ispitivanje sledećih stavki: stanja površina cevi, spoljašnjih i unutrašnjih, zavarenih spojeva, zavrtnja, spojnica, ventila, šahtova i drugi otvora, obloge i premaza, i instrumenti.

2. Izvršiti merenje debljina zida cevovoda koristeći metode bez razaranja, najčešće merenje debljine zida ultrazvukom.

3. Izvršiti detaljnu procenu koristeći IBR tehnike za pojedine stavke uočene tokom vizuelnog pregleda.

4. Simulirati rad sistema kontrole za hitne slučajeve.

5. Izvršiti test opterećenja za poređenje protiv hidrauličnog udara i projektnih kriterijuma da se obezbede sigurni uslovi rada.

6. Projektanti treba da ocene podatke dobijene tokom ispitivanja cevovoda. Ova procena treba da uključi zadatke povezane sa podacima i naponskom analizom i utvrdi da li je cevovod u skladu sa definisanim kriterijumima prihvatljivosti.

Plan inspekcije je ključni element uspešne procene stanja cevovoda i treba da sadrži sledeće stavke:
1. Obim i cilj ispitivanja,

2. Listu osoblja koje je uključeno ili potrebno,

3. Kontrolnu listu stavki koje treba pregledati,

4. Datume i vremena ispitivanja,

5. Listu zaustavnih tačaka i opreme koje se označene kako bi se osigurala bezbedno ispitivanje cevovoda.

\subsection{Analiza otkaza cevovoda}

Relevantne informacije su skoro uvek dostupne. Problem je to što ili nisu poznate/dostupne pravim ljudima ili njihov značaj nije cenjen. Postoje unikatni otkazi i katastrofe, ali najčešće kod svakog otkaza postoje slični događaji u prošlosti koji su mogli da rezultuju otkazom, ali iz nekog razloga nisu.

Model otkaza "Švajcarski sir" izložio je James Reason 2000. godine u Britanskom Medicinskom žurnalu [7]. Model je prikazan na slici 1.

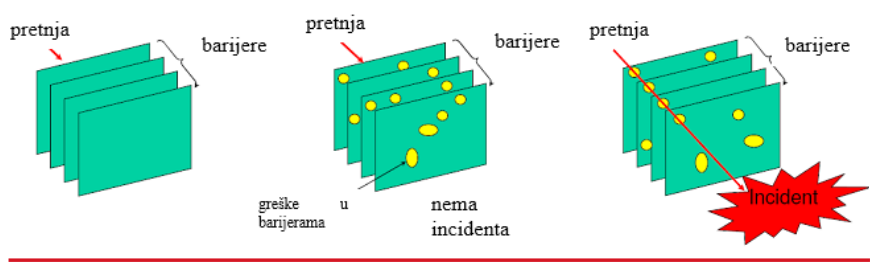

Slika 1: Model otkaza "švajcarski sir”. Prikaz barijera u sistemu koje pomažu da se spreči incident [7]

Hipoteza osnovnog modela je da se "nesreće" mogu pratiti na jednom ili više nivoa grešaka. Obično se navode kao:

- $\quad$ organizacioni uticaji;

- nebezbedan nadzor;

- $\quad$ preduslovi za nebezbedna dela i

- same nebezbedne radnje.

U modelu "švajcarskog sira", odbrana organizacije protiv neuspeha modelirana je kao serija barijera, predstavljenih kao listovi švajcarskog sira. Rupe na sirevima predstavljaju pojedinačne slabosti u pojedinim delovima sistema i stalno se razlikuju po veličini i položaju u svim listovima.

Sistem u celini proizvodi neuspehe kada se sve rupe u jednom trenutku nađu na istoj liniji, odnosno usklade se, dozvoljavajući po Reasonu "putanju prilika za slučaj nesreće", tako da opasnost prolazi kroz sve rupe u svim odbranama, i to dovodi do neuspeha [7]. Ove rupe mogu biti kontinuirano otvarane, zatvarane, a njihove lokacije prebacivane.

Zbog toga, kada pogledamo neuspeh na cevovodu, moramo tražiti raspad sistema, i shodno tome, možemo smanjiti propuste obezbeđivanjem robusnog, multi nivoa, sigurnosnog sistema na mestu, za sve pretnje.

\subsubsection{Uzroci otkaza cevovoda}

Cevovodi mogu propasti i propadaju zbog raznih uzroka - od korozije do pomeranja zemljišta. Uzroci otkaza cevovoda mogu biti sledeći [8]:

- korozija,

- defekti u materijalu, 


\section{PT Tema broja}

- greške ukopavanja,

- prirodne sile,

- ljudski faktor,

- ostale spoljne sile,

- ostali uzroci.

Svake godine, ogromna količina novca troši se na različite oblike kontrolnih mera korozije u cilju očuvanja integriteta cevovoda. $\mathrm{Na}$ žalost, teškoće u vezi sa dobijanjem odgovarajućeg dizajna, predviđanja, monitoringa i strategije usporavanja broje na milijarde dolara izgubljenih u ekonomijama širom sveta koje se odnose na koroziju oštećenja cevovoda i drugih objekata. Istraživanje je pokazalo da je više od $80 \%$ procenata cevovoda koji su otkazali, praćeno na jedan ili drugi način, dok je između 20\% i 65\% od iznosa potrošenog na probleme korozije moglo biti spašeno da je bilo dobrog poznavanja inhibitora korozije, zaštite i/ili kontrole [9]. Korozija cevovoda se može pripisati brojnim uzrocima koji su vezani za fizičkim i hemijskim faktorima i obuhvata oba uslova životne sredine i karakteristike materijala.

Postojanje $\mathrm{H}_{2} \mathrm{~S}, \mathrm{CO}_{2}$, neorganskih i organskih kiselina u radnom okruženju gasovoda može izazvati korozivne nedostatke različitih vrsta [10, 11]. Međutim, postojanje nedostataka poput udubljenja, pukotine, necirkularnosti, ogrebotina i kopči oko korodiranih oblasti u cevovodima čine procene mnogo složenijim. To je zbog toga što efekti tih nedostataka doprinose većim naponima na cevovodu i na kraju će uticati na pritiske rasprskavanja na takvim korodiranim sekcijama. Jedan od takvih nedostataka koji privlači pažnju istraživača je naponska korozija koji se može opisati kao hibridni defekt gde je prslina u korodiranoj oblasti i može iznositi više od $10 \%$ debljine zida cevi [12].

Uzroci korozije cevovoda:

1. Fizički faktori

2. Hemijski faktori

3. Faktori okoline.

Fizički faktori mogu biti strukturalne osobine (osobine materijala, zaostali I operativni naponi, faktori projektovanja, naslage, uključci ili interakcija dva ili više od navedenih faktora) ili osobine produkta (temperatura, pritisak, brzina protoka, čvrste I tečne suspenzije, oblika protoka i interakcije dva ili više od navedenih faktora).

Hemijski faktori uključuju $\mathrm{H}_{2} \mathrm{O}, \mathrm{H}_{2} \mathrm{~S}, \mathrm{CO}_{2}$, organske i neorganske kiseline, sumpor i sumporna jedinjenja, mikroorganizme, ugljovodonike, $\mathrm{pH}$, hemijske varijable, prateće elemente i interakcije dva ili više od navedenih faktora.

Faktori uticaja okoline su sastav naftnog polja, sastav zemlje, temperatura i procenat vlažnosti, priroda radne sredine (slana voda, slatka voda, zemlja...).

Interakcija korozivne okoline $\mathrm{i}$ cikličnih napona u materijalu dovodi do prslina usled naponske korozije. Prsline usled naponske korozije povećavaju rizik od loma cevovoda za prevoz nafte i gasa i izazivaju oko $15-20 \%$ otkaza gasovoda u zavisnosti od njegove starosti $[13,14]$.

Zamr se može opisati kao strukturalno oštećenje materijala zbog napona [15]. Dok ljudski i prirodni fenomeni mogu prouzrokovati lom usled zamora u cevovodima, istraživanje je pokazalo da korozija ima ključnu ulogu u inicijaciji napona usled zamora $[14,16]$ dok ciklično opterećenje doprinosi rastu ovog napona i eventualnom otkazu cevovoda [17]. Procena otkaza usled zamora u cevovodima izazvana korozijom može se izvršiti upotrebom dijagrama napon vek trajanja, deformacija - vek trajanja, linearna elastična mehanika loma, napredovanje prslina i tehnike zasnovane na statistici $[18,19]$. Analiza zamora je od vitalnog značaja za obezbeđivanje održavanja nivoa sigurnosti neophodnih za rad naftovoda i gasovoda.

Bezbedan rad cevovoda pod pritiskom zahteva ublažavanje napona usled zamora izazvanih defektima korozije u radnim okruženjima. Ovi korozioni defekti su prouzrokovani elektrohemijskom reakcijom vode i železa koje sadrži materijal cevovoda u prisustvu $\mathrm{CO}_{2}$ (slatka korozija), $\mathrm{H}_{2} \mathrm{~S}$ (kisela korozija) i / ili mikroorganizmi (mikrobiološki indukovana korozije) kao što su bakterije. Mesta lokalizovanih korozija cevovoda su tačke inicijacije korozionih prslina zbog cikličnih opterećenja izazvanih na cevovodu radnim pritiskom. Prsline usled naponske korozije se javljaju kod niskih i visokih pH okruženja i potencijalno prouzrokuju lom usled zamora u 20-25\% slučajeva u zavisnosti od starosti cevovoda.

\subsubsection{Porast vandalizma, terorizma, sabotaže i krađe}

Cevovodi mogu biti napadnuti od strane vandala ili terorista, i mogu biti zamišljena meta za lopove.

Nije lako sprečiti neprijateljske, naoružane grupe koje napadaju gasovod, a posledice napada i krađe mogu biti ozbiljni: stotine ljudi umiru od ovih dela svake godine. Druga posledica toga može biti nestašica goriva ili porast cena lokalno, nacionalno ili čak na međunarodnom nivou.

Cevovodi su laka meta za vandale, posebno nadzemnih cevovoda. 2001. godine naftovod na Aljasci je bio vandalizovan od strane pijanog lovca koji je više puta pucao na cevovod dok nije ispušteno

1.000.000 barela nafte. Rezultat je bio račun za čišćenje od 17 miliona dolara, a osam miliona dolara su bili honorari I porezi. Pijanac je kasnije uhvaćen i zatvoren na 16 godina i kažnjen sa 17 miliona dolara.

Naftna i gasna industrija su mete često napadnute od terorista [20, 21]. Objekti za proizvodnju nafte i gasa su ciljevi "visoke vrednosti", i često ih napadaju, ali ovi objekti su relativno jednostavni za zaštitu. Oni predstavljaju iste sigurnosne probleme kao i svaka druga meta, a time i mogu biti zaštićena istim sigurnosnim merama. Nažalost, cevovode je teško zaštititi i lako se mogu oštetiti. Oni se prostiru na velikim razdaljinama, a njihova lokacija može biti postavljena na veb sajtovima ili u literaturi kompanije. Pored toga, tipičan napad može uključivati 2 ili 3 teroriste, tri lopate, eksploziv od $5 \mathrm{~kg}$, rolnu žice i bateriju.

Srećom, cevovodi nisu glavna meta za teroriste, jer ne mogu da generišu publicitet. Ipak, sabotaža i terorizam su u porastu širom sveta, a sistemi cevovoda su primarni ciljeve.

Neki od primera sabotaže i terorizma:

- Sabotaža na naftovodu u Kolumbiji 2001. koštala je Occidental Petroleum u iznosu od 445 miliona dolara zbog izgubljene proizvodnje. Kolumbijski naftovod od je napadnut 654 puta od strane Nacionalna oslobodilačka vojska, ili "ELN", od 1986. 
- Irački sistem gasovoda je redovno meta: jedan napad na glavni naftovod u severnom Iraku 2003. godine je izazvao gubitak od 7 miliona dolara / dan. Između 2003. i 2007. godine prijavljeno je 449 napada na iračke naftovode [22]. Ova infrastruktura je zaštićena od strane iračke vladine Službe za zaštitu objekata i Koalicije koja čini desetine hiljada vojnika i 14.000 privatnih službenika obezbeđenja koji su zaštitili ove infrastrukture.

Vlade deluju; na primer, ruska vlada je dozvolila svojoj naftnoj kompaniji, Gazprom, da formira privatnu armiju za zaštitu svoje infrastrukture [22].

Krađa proizvoda iz cevovoda postaje glavni uzrok otkaza u mnogim cevovodima širom sveta. Krađa se dešava u siromašnim zemljama i odražava društvene probleme i teškoće.

\subsection{Analiza rizika i bezbednosti}

Uspešno sprovedena inspekcija cevovoda mora da uključi analizu rizika i bezbednosti i da se pripremi za ispitivanje cevovoda. Treba se uveriti da svi zaposleni koji rade na lokaciji imaju kopiju analize rizika i bezbednosti i da su pročitali sadržaj, razumeli zahteve bezbednosti za poslove koje obavljaju, i da će implementirati zahteve bezbednosti u svakom trenutku tokom rada na terenu[5].

Neke stvari koje bi trebalo da budu deo analize rizika i bezbednosti ispitivanja cevovoda su:

1. Lista kontakta za izveštavanje u slučaju nesreće.

2. Lista za hitne telefonske brojeve.

3. Lista adresa i pravaca za lokalne bolnice.

Lista provere bezbednosti sadrži neke, ali ne sve, od ovde navedenih stavki:

- Sva oprema i objekti treba da imaju zaštitne oznake postavljene, od strane ovlašćenog osoblja, na komandama, vratima i ulazima. Oprema koja je van pogona mora biti zaključana ili otvorena u slučaju stepenica. Izlazi ili ventili koji kontrolišu ulazak vode u suvi prostor treba da se nalaze u zatvorenom položaju.

- Budite sigurni da su sve operativne tačke preseka utvrđene pre ulaska u cevovod, penjanje na merdevine, ili čak šetnje kroz pogon.

- Idite kroz kontrolnu listu sigurnosnih stavki sa licem koje vodi ispitivanje.

- Vertikalni merdevine obično zahtevaju platforme na svakih 20 metara; za merdevine visine više od 6 metara potrebni su zaštitni šlemovi ili zaštitna oprema za penjanje. Privremene skele ili merdevine treba pravilno montirati i osigurati osoblje pre korišćenja. Osoblje treba da koristi sigurnosni pojas.

- Ne sme se penjati vertikalnim ili strmim merdevinama prebrzo.

- Vazduh u cevovodima treba testirati na sadržaj kiseonika i toksičnih gasova pre i tokom ulaska. Ispitivanje u zatvorenom prostoru zahteva izvor vazduha i ventiltor. Ako ste $u$ nedoumici u vezi kvaliteta vazduha, nositi bocu za disane. Jedna osoba treba da bude napolju u svakom trenutku kada se radi u zatvorenom prostoru. Ukoliko dođe do hitnog slučaja, ta osoba treba da pozove pomoć, a ne da uđe unutra.
- Cevovodi su obično nagnuti i klizavi. Padovi su uobičajeni. Treba nositi gumene čizme sa sigurnosnim đonovima i čeličnih prstima i uvek oprezno.

- Budite oprezni prilikom hodanja na vrhu cevovoda pod pritiskom. Budite oprezni u blizini vode pod pritiskom koja curi. Uraditi vizuelno ispitivanje prvo iz daljine

- Budite oprezni prilikom pokretanja ruku preko neobloženog metala jer su ivice često oštre.

- adekvatno osvetljenje treba uvek biti obezbeđeno.

Program bezbednosti cevovoda je od velikog značaja za uspešan rad i održavanje cevovoda. Metodologija programa bezbednosti cevovoda može da se definiše u 4 koraka:

1. Ustanoviti osnovna stanja,

2. Uspostaviti inspekciju, nadzor, i dokumentaciju plana,

3. Implementacija dokumentovanog programa održavanje $i$ reparacije,

4. Periodični sveobuhvatni pregled stanja.

Korak 1 - Uspostavljanje osnovnih uslova - treba da da sveobuhvatan opis sistema, zatim da definiše kriterijume projektovanja, da definiše opasnosti i rizike i da sumira fizičko stanje.

Korak 2 - Specifična inspekcija, monitoring i dokumentacija podrazumeva da različiti delovi cevovoda će imati različite kritične komponente. U ovom koraku je potrebno uraditi procena debljine i korozije cevovoda, koncentrisati se na tunele visoke vlažnosti I koji su u kontaktu sa betonom i zemljištem, ispitivati vakuum ventile, dokumentovati stanje oslonaca, kritički ponavljati posmatranja lokacija i napraviti listu inspekcija za proveru da se održi konzistentnost i potpunost.

Korak 3 - Documentacija inspekcije, održavanja i popravke Potrebna je samo mala modifikacija postojećim procedurama da pouzdanije dokumentuje sve podatke za buduće analize.

Korak 4 - Periodični sveobuhvatni pregled stanja - Ili eksterno ili interno osoblje da uradi nezavisnu evaluaciju / reviziju. Frekvencija 5 do 15 godina, kao i posle specijalnih događaja (npr zemljotresa).

Efektivni program treba da bude:

- Pouzdan da otkrije probleme

- Lako razumljiv

- Pogodan i koristan za radno osoblje i osoblje za održavanje

- Isplativ

Važno:”Očekivati neočekivano".

\subsection{Tehnike inspekcije cevovoda}

Inspekcije cevovoda uključuju sledeće:

- Merenje debljina i dimenzije

- Koncentracija na povezivanja cevi

- Oslonci

- $\quad$ korozije na dodirnim površinama čelika i betona

Kod inspekcija cevovoda koji su u eksploataciji praktikuju se dve vrste inspekcija: letimičan pregled i sveobuhvatni pregled.

Svrha letimičnog pregleda je napomenuti bilo kakve uočljive 
promene u stanju. Letimičan pregled najčešće izvodi zaposleno osoblje jednom nedeljno, mesečno ili kvartalno. Promene u stanju se napominju za dalja ispitivanja.

Sveobuhvatni pregled / evaluacija: Svrha je da se razmotri stanje, bezbednost i rizik postojećeg cevovoda i obavljaju ga inženjeri koji razumeju osnove projektovanja i stvarnog stanja cevovoda. Ako su nedostaci notirani, oni mogu biti rešeni repariranjem, obnavljanjem ili zamenom.

Merenja fizičkih dimenzija i oblika cevovoda treba preduzeti tokom terenske inspekcije da se provere informacije prikazane na tehničkom crtežu. Linija i balansiranost cevovoda se proveravaju da se potvrdi saglasnost sa originalnim projektom. Odstupanje linije ukazuje na naginjanje cevovoda koje bi moglo da izazove lom cevovoda ako bi pokreti bili dovoljno veliki da se spojevi otvore. Inspektor treba da tražiti znake odstupanja, uključujući i slomljene potisne blokove, ovalnost cevovoda, i pukotine u zemlji koja okružuju cevovod. Pomeranje cevi, takođe, može prouzrokovati asimetričnost vijčanih spojnica. Pomeranja linije spojnica mogu da izazovu napone u zaptivačima što dovodi do curenja. Strukturalni stanje cevovoda treba procenjivati određivanjem integriteta i dostupnom debljinom zida. Merenja debljine zida uzimaju se i evidentiraju na odabranim lokacijama duž cevovoda. Detaljno merenje debljine zida cevovoda će omogućiti tačnu strukturnu procenu cevovoda. Istorija ovih čitanja može da ukaže na očekivani godišnji pad u debljini. Ove čitanja može se uzeti lako na spoljnoj strani cevovoda, eliminišući potrebu za pražnjenjem cevovoda. Za ukopane cevovode, očitavanja debljine zida mogu uzeti iz unutrašnjosti tokom perioda pražnjenja cevovoda.

Merenja prečnika cevovoda se vrši da bi se odredila ovalnost cevovoda. Merenja se vrše u horizontalnom i vertikalnom pravcu. Određena tolerancija kod ovalnosti cevovoda je prihvatljiva. Ako se merenja razlikuju, ukazujući na ovalnost cevovoda, moraju se istražiti uzroci. Tankozidni cevovodi su najviše podložni gubitku svog oblika i najskloniji pojavi ovalnosti. Međutim, debelozidni takođe mogu da izgube svoj oblik. Neki od najčešćih uzroka ovalnosti cevovoda su:

1. Kada su unutrašnji pritisci niski i u proračun debljine zida nije uključen efekat težine tečnosti cevovoda.

2. Nepravilna instalacija zakopanih ili delomično zakopanih cevovoda

3. Delovi cevovoda koji nisu namenjeni za spoljne opterećenja i ponovo su napunjeni u zemljištu ili zatvoreni u betonu.

Stepen erozije i korozije, kao i stanje obloge, su veoma važni za bezbedan rad cevovoda. Erozije ili kavitacija unutar cevovoda mogu biti uzrokovane turbulentnom strujom (obično se javlja u diskontinuiteta i krivinama), velikom brzinom, ili abrazivnim materijalom koji se provodi u vodi. Obim istanjenja zida izazvanog korozijom i erozijom može biti teško odrediti vizuelno pa su neophodna dalja ispitivanja.

\subsection{Oblici propusta}

Količina naučne i inženjerske literature o otkazima cevovoda $u$ hidroelektranama nije baš impresivna. To je uglavnom zbog činjenice da informacije o ovom tipu otkaza se nerado dele. Nažalost, takva situacija ne omogućava objavljivanje podataka o prethodnim kvarovima koji bi mogli da se koriste da bi se smanjio broj otkaza u budućnosti i poveća operativna sigurnost hidroelektrana [23].

Rad Bonina [24] opisuje se oštećenje turbine u Oigava Pover Station, Japan, 1950. uzrokovano otkazom cevovoda, izgleda da je redak izuzetak. Otkaz u Oigava je izazvan hidrauličnim udarom zbog naglog zatvaranja leptir ventila. Tri osobe su poginule usled poplave u komori mašine. U literaturi se često predstavlja problem hidrauličnog udara [25]. Arington [26] je predstavio nekoliko veoma ozbiljnih otkaza igličastog ventila na Bartlett Dam (SAD) i lom čeličnog cevovoda u Oneida Station hidroelektrani (United States), oba izazvana hidrauličnim udarom usled zatvaranja ventila. Kao posledica toga, pet ljudi je poginulo.

Osnovni oblici propusta koji dovode do loma su prikazani na slikama 2 -5 [27]. Najčešći i najvažniju su: lom usled unutrašnjeg pritiska, opšte izvijanje, lokalno izvijanje i neadekvatni oslonci.

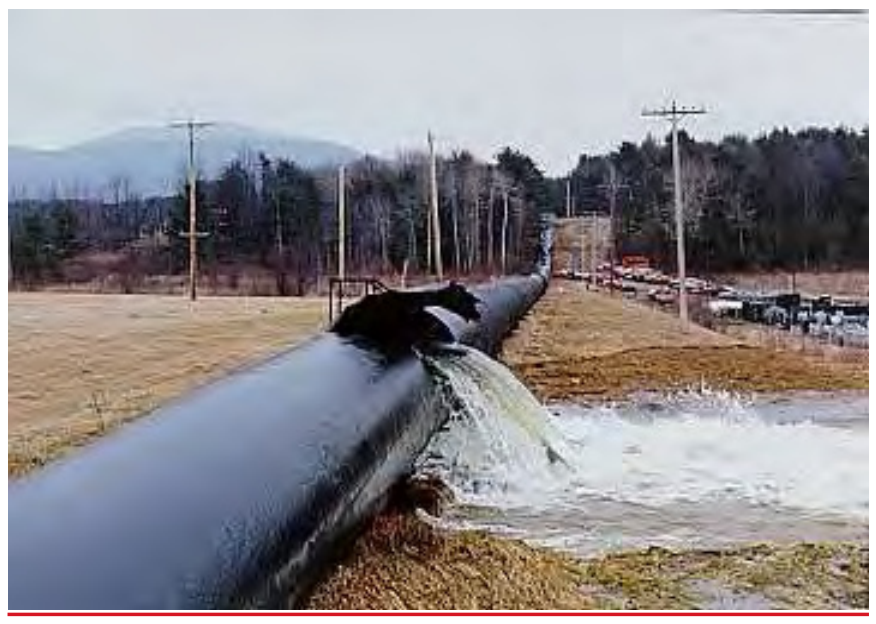

Slika 2: Lom nastao u zoni uticaja toplote [27]

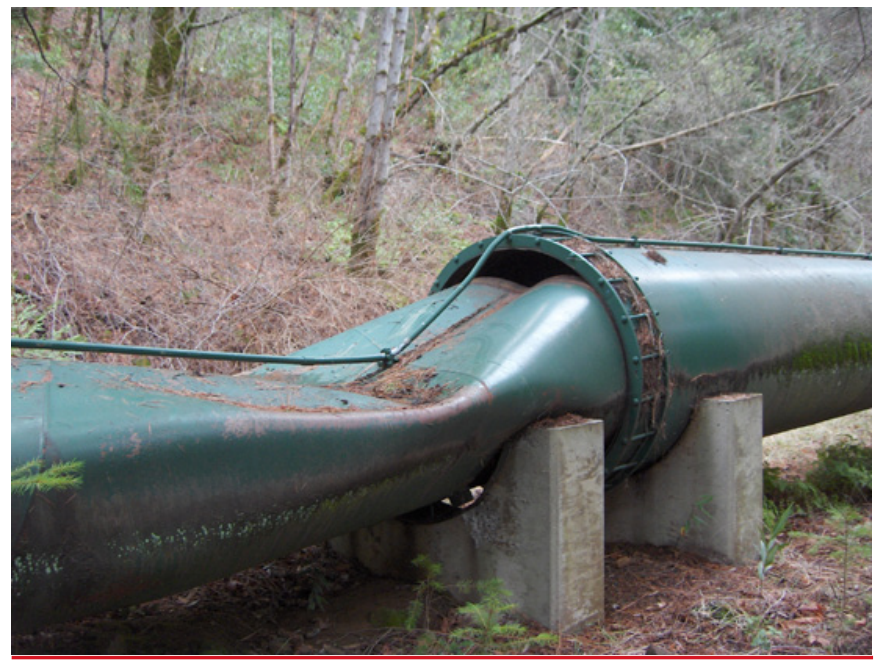

Slika 3: Lom usled izvijanja cevovoda [27

U sledećem primeru otkaz cevovoda se dogodio u Łapino hidroelektrani kojom upravlja ENERGA Gdanjsk energetska kompanija [23]. Elektrana je izgrađena 1927. godine na reci Radunia, $15 \mathrm{~km}$ jugozapadno od Gdanjska, Poljska. Voda iz gornjeg rezervoara dovodi se u turbine jednim cevovodom i odvaja u kućištu elektrane (sl. 1). 


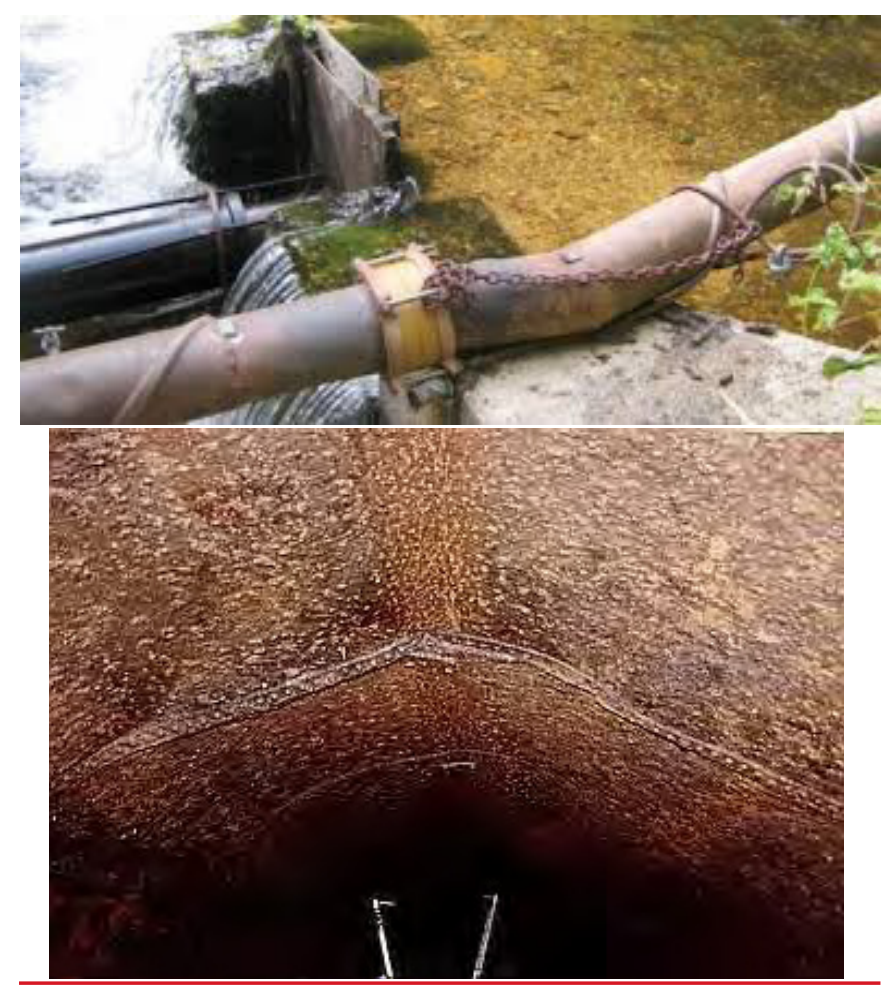

Slika 4: Lokalno izvijanje najverovatnije usled koncentracije opterećenja [27]

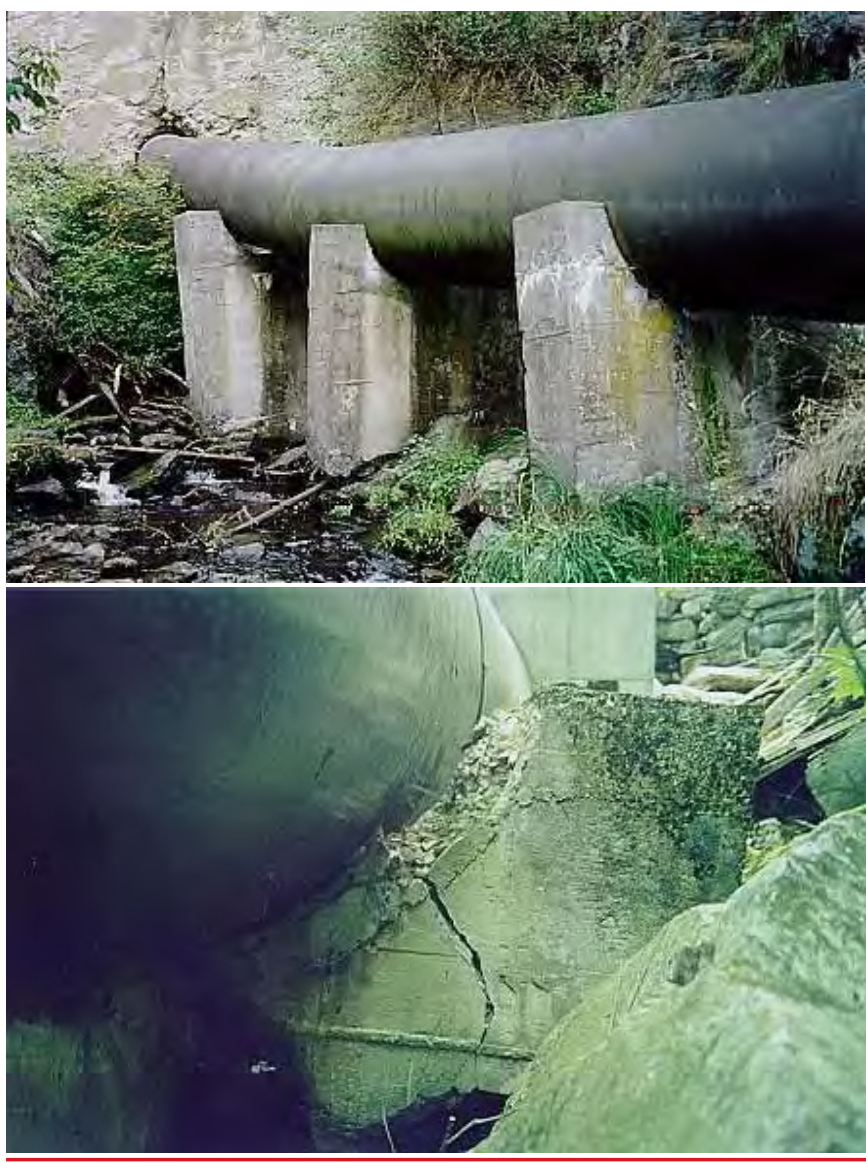

Slika 5: Neadekvatni oslonci [27]
Gornji deo cevovoda, uzvodno od prve račve je betonski cevovod; dok je donji deo zavarena čelična konstrukcija. Elektrana je opremljen sa dva identična seta generatora (Fig. 2) i svaka sastoji od dve horizontalne Francis turbine i generatora.

U decembru 1997. godine, tokom ispitivanja, čelična cev za snabdevanje turbine vodom je pukla. Mašinska hala je poplavljena do visine od 2,5 m iznad nivoa poda.

Glavno oštećenje, odnosno lom omotača cevovoda, bilo je u levoj grani cevovoda (gledajući nizvodno) na mestu gde se grane cevovoda za snabdevanje vodom u set generatora br 1 . Kao rezultat pucanja, na konusnoj površini sekcije cevovoda (duge $2 \mathrm{~m}$, sa minimalnim i maksimalnim prečnikom od 2,1 i 2,4 m, respektivno), i deo usisne cevi snabdevanja vodom turbine seta 1 su se podelili duž šava njihovog spoja (debljina zida cevovoda razbijene sekcije bila je $8 \mathrm{~mm}$ ). Karakteristična odlika destrukcije je prelom u kontinuitetuu od gornjeg longitudonalnog šava do kružnih spojeva u dva poprečna preseka. Izgled preloma površine duž zavarenog spoja je karakterističan za krti lom (slika 4.). Pored razaranja u levom ogranka cevovoda, desna strana istog cevovoda je bila izložena prslinama. Prsline su pronađene u zavarenom spoju u uglu spoja između cevovoda i priključne cevi turbine seta br 1 (slika 5).

Ova pukotina se pojavila duž podužnog šava spoja $(0,7 \mathrm{~m}$ dugačak), kao u glavnom materijalu ulazne cevi (0.3 m dugačka). Vredno je napomenuti da je ova tačka poklopila sa površinom plastičnih deformacija polomljenog dela levog ogranka cevovoda. Ova tačka ukazuje da je povezivanje konusnog dela cevovoda sa ulaznom cevi i bio tačka nastanka pucanja uzrokovana prekomernim pritiskom. Nakon peskarenja, nepolomljeni omotač cevovoda je vizuelno ispitan, tokom kojeg je primarni pažnja posvećena zavarenim spojevima. Inspekcija je otkrila brojne nedostatke u zavarenih spojeva. Ovi nedostaci su se uglavnom odnosili na neprimenjenoj termičkoj obradi posle zavarivanja na spoljašnjim površinama cevovoda i neodgovarajućoj geometriji zavara. Pokazano je da u svetlu sadašnjih zahteva za bezbednost, defekti u zavarenom spoju nisu bili dozvoljeni i ne mogu da garantuju bezbedan rad cevovoda.

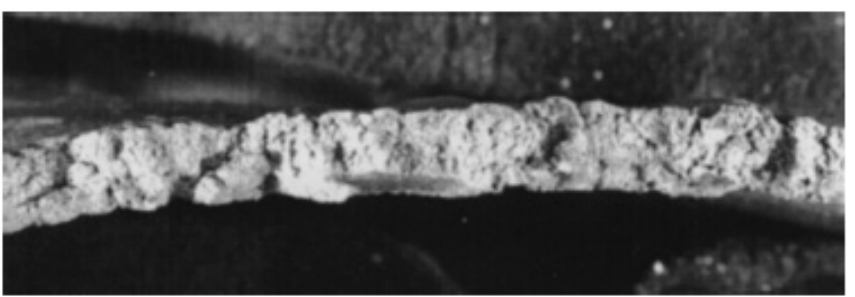

FIG. 4. Macroscopic Picture of Cracked Weld Joint

Slika 6: Mikrografski snimak loma u zavarenom spoju [23]

Sledeći primer, otkaz cevovoda hidroelektrane „Perućica“ je ukazao na značaj obezbeđenja kvaliteta u zavarivanju [28]. Iako nije došlo ni do krtog loma ni do procurivanja, pojava prslina u zavarenom spoju je zahtevala preduzima-nje mera radi sprečavanja eventualnog isključivanja elektrane iz pogona.

Brojne prsline, dužine i do nekoliko stotina milimetara, su se pojavile u zavarenom spoju posle 10 godi-na eksploatacije, od kojih su neke probile šav. Ispitivanjem se došlo do zaključka da su u pitanju hladne prsline, koje su se pojavile zbog nedovoljnog predgrevanja i 
zbog krutosti cevovoda pri zavarivanju prstena. Psline su dalje rasle pod uticajem korozije i usled preopterećenje koje je cevovod pretrpeo u početnoj fazi rada, praćeno vibracijama. Izvedena je sanacija svih segmenata gde su uočene prsline [28]. Na slici 8. su prikazane prsline nastale na kružnim spojevima prstena.

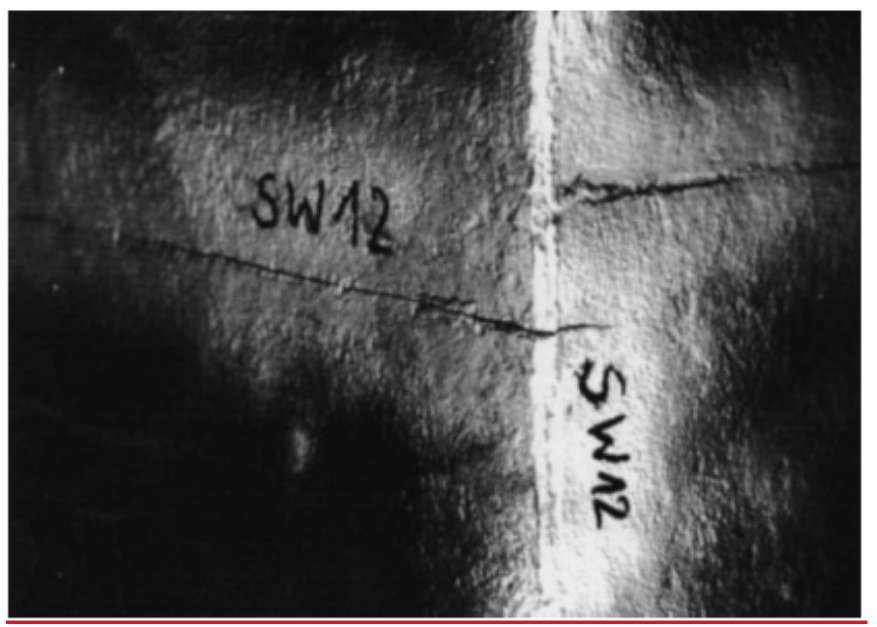

Slika 7: Prsline u cevovodu [23]

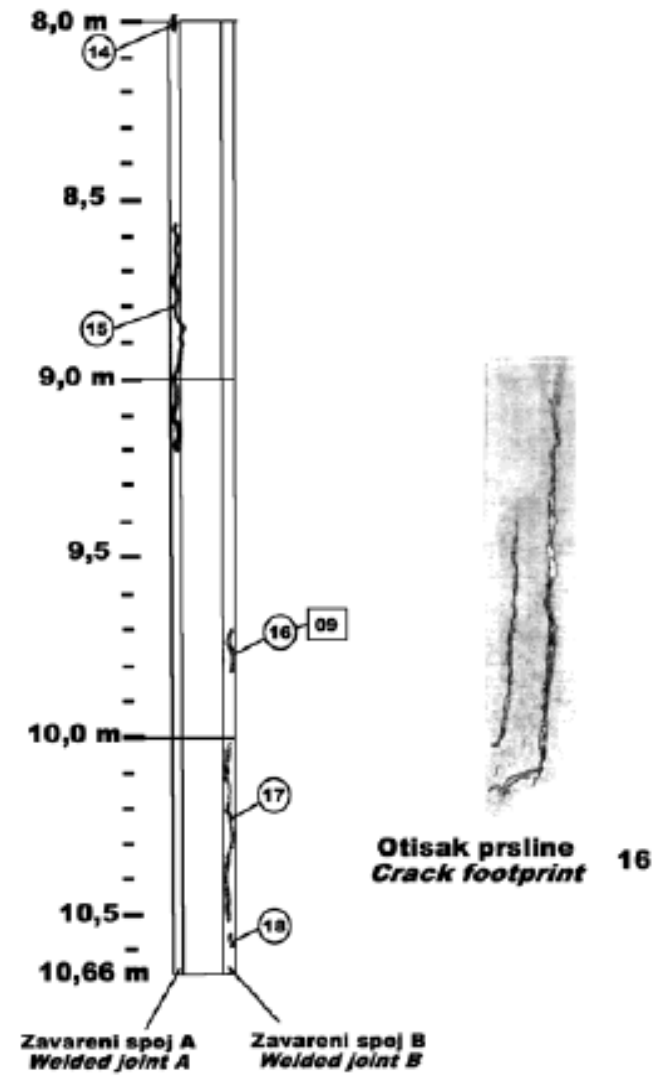

Slika 8: Delimičan prikaz rasporeda prslina na kružnim spojevima prstena [28]

\section{4 \\ Zaključak}

U radu je analizirana i diskutovana inspekcija cevovoda tokom njihovog veka upotrebe. Mnogi od cevovoda su preko 40 godina u upotrebi. Korozija i erozija smanjuju njihovu čvrstoću, pa je neophodno redovno održavati i ispitivati ove cevovode, često i na kraći period od propisanog zakonom.

Plan inspekcije je ključni element uspešne procene stanja cevovoda.

U modelu “švajcarskog sira”, primenjenog na cevovode, prikazano je da može da dođe do katastrofe samo ako se sve greške usklade.

Cevovodi otkazuju iz raznih razloga a najščešći uzroci su korozija, defekti u materijalu ili projektovanju, u ukopavanju, prirodne sile, ljudski faktori i ostalo. Takođe, cevovodi mogu biti napadnuti od strane vandala ili terorista, i mogu biti meta za lopove. Program bezbednosti cevovoda je od velikog značaja za uspešan rad i održavanje cevovoda. Metodologija programa bezbednosti cevovoda može da se definiše u sedećim koracima: ustanoviti osnovna stanja, uspostaviti inspekciju, nadzor, i dokumentaciju plana, implementirati dokumentovani program održavanja i reparacije i periodični sveobuhvatni pregled stanja.

Uspešno sprovedena inspekcija cevovoda mora da uključi analizu rizika i bezbednosti i da se pripremi za ispitivanje cevovoda.

\section{Zahvalnost}

Rad je nastao zahvaljujući Ministarstvu za prosvetu, nauku i tehnološki razvoj Republike Srbije, iz projekata TR 37021 i TR35040.

\section{Literatura}

[1] ***, Pravilnika o pregledima opreme pod pritiskom tokom veka upotrebe, "Sl. glasnik RS", br. 87/2011

[2] ***, Pravilnik o tehničkim zahtevima za projektovanje, izradu $i$ ocenjivanje usaglašenosti opreme pod pritiskom, "Sl. glasnik RS", br. $87 / 2011$

[3] US DOT. Pipeline and Hazardous Materials Safety Administration $<$ https://hip.phmsa.dot.gov/analyticsSOAP/saw.dll?Portalpages $>$

[4] ***, SRPS EN 13480-5, Industrijski metalni cevovodi-Deo 5: Ispitivanje i kontrolisanje

[5] McStraw, B., Inspection of steel penstocks and pressure conduits, Facilities instructions, standards, and techniques, 2-8, (2000), Hydroelectric Research and Technical Services Group, United States Department of the Interior Bureau of Reclamation Denver, Colorado [6] American Society of Civil Engineers, Guidelines for Inspection and Monitoring of In-Service Penstocks, by Task Committee Inspection and Monitoring of In-Service Penstocks of the Energy Division of ASC American Society of Civil Engineers, Reston, VA 978-07844-0378-5 (ISBN-13) | 0-7844-0378-3 (ISBN-10), 2000

[7] Reason,J., Human error: models and management, British Medical Journal 320, (2000) 7237, pp. 768-770.

[8] Ossai, C. I., Boswell, B., Davies, I.J., Review, Pipeline failures in corrosive environments - A conceptual analysis of trends and effects, Engineering Failure Analysis, 53 (2015) 36-58.

[9] Miller, R., Why pipes matter: the importance of clad pipes in the oil and gas industry; $2013 \mathrm{http}$ //breakingenergy.com/2013/03/15/ why-pipesmatter-the-importance-of-clad-pipe-in-the-oil-and-gas/ 
[10] Nesic, S., Key issues related to modelling of internal corrosion of oil and gas pipelines - a review. Corrosion Science 49, (2007), pp. 4308-38.

[11] Singer, M., Brown, B., Camacho, A., Nesic, S., Combined effect of carbon dioxide hydrogen sulfide and acetic acid on bottom-of-theline corrosion. Corrosion 67 ,1, (2011), pp.015004-01 - 015004-16.

[12] Bedairi, B., Cronin, D., Hosseini, A., Plumtree, A., Failure prediction for crack-in-corrosion defects in natural gas transmission pipelines. Int J Press Vessels Pip 96,97 (2012), pp. 90-99.

[13] Ahmed, T.M., Lambert, S.B., Sutherby, R., Plumtree, A., Cyclic crack growth rates of $X-60$ pipeline steel in a neutral dilute solution. Corrosion (NACE), 53,7, (1997), pp. 581-590.

[14] Pilkey, A.K., Lamberf, S.B., Plumtree, A. Stress corrosion cracking of X-60 line pipe steel in a carbonate-bicarbonate solution. Corrosion Science, 51,2, (1995), pp. 91-996.

[15] Singh, M., Markeset, T., Simultaneous handling of variability and uncertainty in probabilistic and possibilistic failure analysis of corroded pipes. International Journal of System Assurance Engineering and Management, 5, (2014), pp.43-54.

[16] Ossai, C.I., Advances in asset management techniques: an overview of corrosion mechanisms and mitigation strategies for oil and gas pipelines. ISRN Corrosion, vol. 2012. http://dx.doi. org/10.5402/2012/570143, Article ID 570143.

[17] Meresht, E.S., Farahani, T.S., Neshati, J., Failure analysis of stress corrosion cracking occurred in a gas transmission steel pipeline. Eng Fail Anal , 18, (2011), pp. 963-970.

[18] Breton, T., Sanchez-Gheno, J.C., Alamillac, J.L., AlvarezRamirez, J., Identification of failure type in corroded pipelines: a Bayesian probabilistic approach. J Hazard Mater, 179, (2010), 628634.

[19] Sinha, S.K., McKim, R.A. Probabilistic based integrated pipeline management system, Tunn Undergr Space Technol 22, (2007), 543-552.

[20] M. Stone., The Issue of Terrorism, World Pipelines, (2005), pp. 22-27.

[21] R. Brown., Iraq's Pipeline War, World Pipelines, (2005), pp. 22-31.

[22] L. Morrissey., Pipeline security - a pipe dream?, World Pipelines, (2007) p.17. Seehttp://www.iags.org/iraqpipelinewatch.htm for other data.

[23] Adamkowski, A., Case Study: Lapino Powerplant Penstock Failure, Journal of Hydraulic Engineering, 127, (2001),pp. 547 - 555. [24] Bonin, C. C. Waterhammer damage to Oigawa power plant, Trans. ASME, J. Engrg. for Power, Series A, 82(2), 111-119.

[25] Chaudhry, M. H. Applied hydraulic transients, Van Nostrand Reinhold, New York, 1979.

[26] Arrington, R. M., Proc. 3,rd ASME/JSME Joint Fluid Engrg. Conf., Failure of water-operated needle valves at Bartlett Dam and Oneida station hydroelectric plant, San Francisco, Calif., 1999, pp. $1-5$.

[27] Kahl, T.L., Penstock Condition Assessment, Northwest Hydro Association, Technical Seminar, P.E. Kleinschmid, 2012.

[28] Sedmak, S., Sedmak, A., Integritet cevovoda hidroelektrane, Integritet i vek konstrukcija 5, (2005), 2, pp. 59-70.

\author{
Autori \\ Sanja PETRONIĆ \\ Univerzitet u Beogradu \\ Institut za nuklearne nauke "Vinča" \\ Mike Petrovića Alasa 12-14, 11351 Vinča, Beograd

\section{Radomir JOVIČIĆ} \\ Inovacioni centar Mašinskog fakulteta u Beogradu, \\ Kraljice Marije 16, Beograd

\section{Aleksandar SEDMAK} \\ Mašinski fakultet Univerziteta u Beogradu \\ Kraljice Marije 16, Beograd

\section{Aleksandar PETROVIĆ \\ Mašinski fakultet Univerziteta u Beogradu \\ Kraljice Marije 16, Beograd} \\ Aurel - Valentin BIRDEANU \\ National R\&D Institute for Welding and Material Test- \\ ing - ISIM Timişoara, Rumunija \\ Dragan VASALIĆ \\ Univerzitet u Beogradu \\ Institut za nuklearne nauke "Vinča" \\ Mike Petrovića Alasa 12-14, 11351 Vinča, Beograd
}

\section{Članski popust na izdanja SMEITS-a}
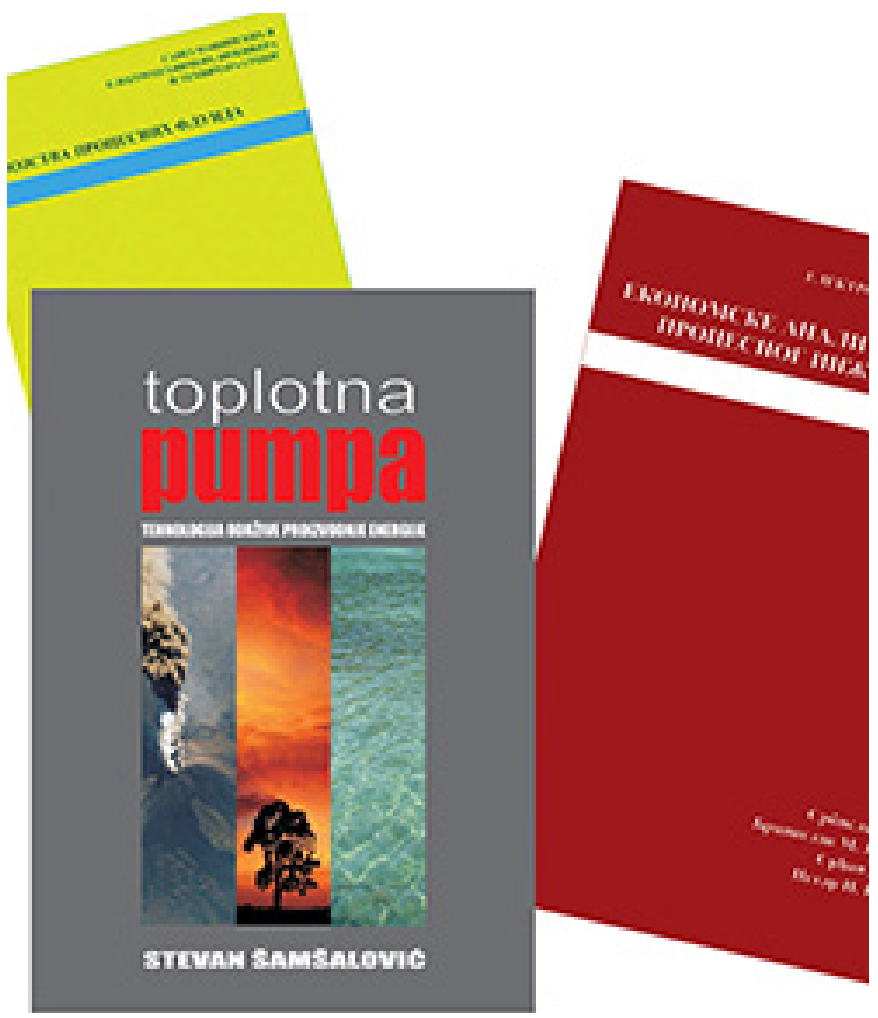